\title{
Identification of Effective Components for Creation of Rituals in Public Spaces, Promotion of Social Values and Capital
}

\author{
Mohammad Moayedi ${ }^{*}$, Seyed Komeyl Salehi, Reza Kheyroddin \\ Urbanism Department, School of Architecture \& Urbanism, Iran University of Science \& Technology (IUST), Tehran, Iran
}

Email address:

M_moayedi110@yahoo.com (M. Moayedi), seyedkomeyl@gmail.com (S. K. Salehi), reza_kheyroddin@iust.ac.ir (R. Kheyroddin)

To cite this article:

Mohammad Moayedi, Seyed Komeyl Salehi, Reza Kheyroddin. Identification of Effective Components for Creation of Rituals in Public Spaces, Promotion of Social Values \& Capital. International Journal of Science, Technology and Society. Special Issue: Research and Practice in Architecture and Urban Studies in Developing Countries. Vol. 3, No. 2-1, 2015, pp. 81-88. doi: 10.11648/j.ijsts.s.2015030201.26

\begin{abstract}
An important aspect effective on city sustainability is 'Social sustainability' heeded such that numerous connoisseurs consider 'social wealth' a criterion of urban social sustainability. Also social rituals and values today reckon cultural source significance that when targeted on social relation production in society can develop social capital. An important bedding of ritual and urban social relations manifestation is urban public spaces. These spaces are considered association of nation shared perceptions carrying along socio cultural heritage, collective memory recreation and a site to present common social rites and values. Therefore, the significance of rituals at present just like urban public spaces during various cycles has impelled its essentiality to undertake replication on citizen's cultural socio and psychological needs. By application of analytical descriptive method and library studies, this article is in addition to studying and analyzing the relative concept to discover effective components on urban public spaces for boosting public investment in consideration of rites and ritual ceremonies. That is why these findings truly indicate that ritual ceremony is an occasion for nations that on the basis of inner self inclination originating from creeds and beliefs to voluntarily and spontaneously attend public spaces and participate in activities. Hence, the impression of rituals and its relation with nation presence has also a serious impact on spatial structure. In addition, by promotion of public attendance and targeted social relation level promotion in urban public spaces, social investment is also effected by components such as attachments, dependency, commitments, participation and belief and creeds fortifications.
\end{abstract}

Keywords: Social Sustainability, Social Capital, Ritual, Urban Public Spaces

\section{Introduction}

Replication and opportunities to social needs for individual social integration requires a favorable physique base to enable individual login stop into space. Consequently, public space and specifically spatial rituals are particularly significant since public have also revealed high enthusiasm and have taken part [1]. Further, in these spaces in addition to skeletal dimension highly affected by social attendance and deliberation, anticipation and creation of social event as well as creation of occasions for participation can plan to promote sense of place $[2,3]$ and social capital. That is why rites and ritual ceremonies are still exclusive and highly effective on nations and society.

On this basis, in addition to rites and ritual ceremonies effectives in the formation of spatial rituals (public spaces) also effects and activates components such as social belong, social cohesion and social integration in spatial rituals socially such that: "Heirichi has introduced four components effective on individual social integration as participation, attachment, commitment and belief. He also states that significance relation exists between components and individual integration in society.'[4]. consequently for the creation of a flourishing spatial ritual enjoying the concepts of social integration requires dimension cognition of quantity and quality spatial. In this paper, concept explanation such as sustainability and social capital, urban public ritual and spatial, the impression of rituals on public spatial for boosting social capital is studied and intends to identify effective components over these spaces. The most important query that this paper seeks to replicate with the assumption of effective rituals in the shaping of urban spaces and the aims of boosting social capital is that can urban public spaces effectuate social sustainability in view of rites 
and ritual ceremonies significance? For this purpose, we therefore applied the descriptive analytical method and library studied to assert social capital components and investigated the quantity of coordination and its relation with spatial ritual and eventually identified the effective factors.

\section{Theoretical Study}

\subsection{Social Sustainability}

In general sustainability is conceived a social transformation in society such that as stated by Belkinge: 'A transformation, development or social systems evolution towards life quality increase of community members in view of their talents and capacities' [5]. Nonetheless, according to Estes: 'Social development seeks improvement of people's material and social welfare at all society level and considers two issues: a) people's satisfaction of basic needs and their fulfillment and b) society ability enhancement for improvement of self-conditions; on this basis, in addition to fulfilling needs, a need to increase freedom for society development is also essential'[6]. A resistant society is based on the parity between freedom and social order in conformity with values and individual morality and social spectrum [7]. Accordingly, Johnson presumes social development is basically to the sense of reinforcing civil society vitality and increments of socio cultural values [8].

On this basis the society cohesion, socio economic security and social empowerment are considered important components of social sustainable development. [9] Further social resistance at architecture scale propounds space that by studying human needs and behavior orient the plan in a way that the relation of human and built environment is established for long period. This issue requires an insight of spatial qualities defined on the basis of individual needs, created by space design reflection. Accordingly, those spatial qualities created for immaterial human needs can during long periods be preserved in space. Consequently, behavioral and physical patterns consistency in space design is quite effective on social resistance. Also, spaces which are in conformity with socio cultural and behaviors reinforce human and (urban) architecture and develop culture and public understanding [10]. According to Habibi: 'All in all, space social resistance is in close relation with space collation and human needs and individual or mass behavior patterns. Hence, on top of space physical stability needs, social resistance is also in relation with sustainability and quality promotion incidental in the inner physique' [11]. Thus, in order to accomplish social resistance in a space three principles must be considered:

- Replication to human basic needs;

- Improve the quality of human environment via cognition of human high non-material requirements;

- Behavioral and physiques patterns consistency [10].

In general, the general features of stable and unstable communities/societies are based on Table 1 .

Table 1. The General Features of Stable Societies.

\begin{tabular}{|c|c|}
\hline Criteria & Stable Society \\
\hline Economic Development & Basic economics progressive, long term commitments, economic stability including majority of citizens \\
\hline Citizenship & $\begin{array}{l}\text { Citizens and active society, long term social supervision, political effective obligations, voluntary section, strong social } \\
\text { capital }\end{array}$ \\
\hline Rule & $\begin{array}{l}\text { Accountable governance systems and society representative, defined strategies and development strategies parity, } \\
\text { theoretical and macroeconomic policies from top to bottom and practical implementation policies from bottom to top }\end{array}$ \\
\hline Social Features & $\begin{array}{l}\text { Abundant skills in work forces, social ethnic diversity, various combination of residents types from socio economic } \\
\text { aspects, community balance, communities with appropriate population }\end{array}$ \\
\hline Urban Design & $\begin{array}{l}\text { Diverse architecture, access to public spaces, higher urban densities, provision of facilities and various services, } \\
\text { buildings equipped for some of the requirements, location institute }\end{array}$ \\
\hline Environmental Dimensions & $\begin{array}{l}\text { Reuse of locations and sites with development ability, reduce and minimize trips, improve the quality of public } \\
\text { transport }\end{array}$ \\
\hline Social Capital & $\begin{array}{l}\text { Boost mutual cooperation and trust between citizens with urban affairs managers, simultaneous consideration of } \\
\text { physical, human and environmental capitals }\end{array}$ \\
\hline Life Quality & Attractive environments, high life quality, social groups activities and attractions \\
\hline $\begin{array}{l}\text { Identity, Sense of belonging and } \\
\text { Safety }\end{array}$ & $\begin{array}{l}\text { Sense of identity and belonging to society, fairness and tolerance against transformations, relation and commitment } \\
\text { between individuals and their past history, low and least level of crime and behaviors and society anomaly }\end{array}$ \\
\hline
\end{tabular}

[12]

\subsection{Social Capital}

As a whole any effort to promote people (urban) communities is considered a long term investment since accomplishment of stability is feasible by local communities [13]. Hence, 'if community capacity building is established on the basis of people's priorities it would lead to social sustainable development.' [14]. 'Social capital with centrality of trust and the product of daily interactions in social networks is one of the most applied concepts in relation with capacity building and social stability' [15]. 'If the applied research indicates social capital increase, it entails society physical and mental health' [9]. Also, this causes costs of reduced transaction, informal relations promotion and facilitating contracts and informal interactions.

Consequently social health increase, reduce crimes, increase unity and attachment to environment, reinforce confidence, better life quality and persistence from indicated outcome of social capital. The type of capital is in relation with internal capital and community cohesion, norms and values which create interactions and also institutions. In fact social capital is like an adhesive that connects and sustains 
communities and without this economic growth and social welfare cannot exist [16].

In general, social capital created by synergistic is by the reason of social interaction assortment in the frame of specific defined structure such that individual ability aggregation shapes collective abilities that has an essence more pervasive and effective from individual type. That is why due to extensive spectrum of its underlying talents can be viewed as one of the effective components of sustainable development among urban communities. As a result, by social capital boosts in urban areas 'local stable societies experience solidarity and cohesion. In addition, liability against private and public life establish unnoticed supervision and public spaces are viewed as stable by citizens. Therefore public spaces find a new role for citizen's connection that increment transactions based on confidence of shaping collective memories' [17].

\subsection{Rites \& Ritual Ceremonies}

Generally 'rituals' is known a ceremonial act separate from non-religion and secular practices including religious and sacred implications [18]. In this respect Bocock reckonns code of practice along with physical demonstrations in relation with symbols [19]. Guffman also percepts rituals wide and extensive observed in daily life and all social interactions. Therefore, 'Rites can be interpreted traditions shaped during long period and in the orients of defining relations and decencies among individuals with one another, society, nature and history. Customs root in people's social beliefs, sensations and identity; that is why they are often held in self-instigated and spontaneous form among population' [20]. Also, 'These cover wide range of individual social behaviour and acts in the society, etc. and are device of visualization and modernization of beliefs and ideologies. This way, beliefs (religious or none and legendary) would be found within the frames of traditions visualized and profound' [21].

For traditions, variegated functions were enumerated, mains being 'exchange of goods and services', 'social cohesion fortification', 'social identity consolidation' and 'a tool for resistance manifestations' and etc.[22]. Hence, it can be stated that: 'Ritual ceremony is applied in particular types of speech and regular practice originating from religious and metaphysic education or for stating religious senses that due to former beliefs it is bounded with people's tradition and history in a region and is a part of daily culture undeniable' [23]. Celebrations and ceremonies rooted in people's credence that its practice during long spontaneous years is known as 'ritual ceremony.'

The most significant performance of rituals and ceremonies ritual is considered for 'exchange of goods and services', 'reinforcement of social cohesion', 'identity consolidation' and a device for indication of resistance' [22]. A 'place for people's gathering', 'provide the grounds for reinforcement and reaffirming commitment against the society to a series of values and creeds', 'offer mental support', 'reduce social struggle among society members', 'community supervision reinforcement' 'indirect conveyance of values and customer' and also 'manifestation of morale parity dimension among society'[23]. City is the most distinct bedding for social epiphany rituals and traditions that if focused can reinforce social sense of belonging, nature and life. The main spaces that provide the epiphany and advent of these rites are urban spaces since these spaces create sense of social gathering and life pleasures by public participation.

\subsection{Urban Public Spaces}

Urban spaces have a more symmetric concept than a normal simple space such that in addition to general features of a space includes aesthetic criteria and complex economic and social values [24]. Also Gehl implies to urban spaces classifications that occur in the third group of urban space activities as 'social activities' that depending on urban space features involves and extensive spectrum of relations. Therefore, the spaces that do not have necessary aspects for relation boosting feasibly outbreak solely by limited activities, depending on the conditions of individuals [2]. Accordingly, urban spaces are scenes for various urban public life activities that shape individual. This dynamic atmosphere are built against sedentary place of work and residence and constitute the main vital components of city, move networks, communication centers and amusement parks in such a way that recently observation of urban spaces has propagated everywhere such as parks, set on foot recreation complexes, gardens and walking centers for various uses[25]. Urban public places have numerous features, the most significant being bedding of 'collective memories shaping', 'creation of sense of place', 'realization of social interaction' and 'ritual unveils and exhibition.'

\subsubsection{Urban Places \& Collective Memories Shaping}

Urban spaces are beds of shaping and recalling individual and collective memories. These spaces are the most important beds of civil life flows; incidences and accident0s occur, occurrences that transform civil life to real one and cause memory shaping - mind is the location of memories accumulation'[26]. Principle to this, at times rituals and practices of ritual ceremonies is a factor of memory shaping envisioned and instigate gathering of mass citizens in urban spaces. Hence, urban spaces are considered as public spaces (any type such as cafeteria, square or street) the representative of collective belonging, social exchange and informal encounters. Here, the universality of the place...is over sense of public life that generates' [27].

\subsubsection{Urban Spaces and Creation of Sense of Place}

In addition to physical factors, urban spaces and environment includes messages, signification and codes. People decode and percept based on roles, expectations, motivations and other factors' [28]. This general sense, created in individual after apprehension and judgment of a specific environment is called 'sense of place'; an essential factor for compatibility of individual with environment and their perpetual presence, the reason of better utilization of environment, user satisfaction increase and finally their sense 
of belonging to the environment and its continuation[29]. Furthermore sense of place is a factor that establishes relations between human and place and creates unity [30]. As a result a set of environmental factors, decent living, rituals, social and credence concepts impact stability and social belong over place [31] and sense of place can be found in places that have distinct distinguished character [32].

\subsubsection{Urban Spaces Beds of Social Interactions}

Since 'urban spaces are considered as social spaces [33]. Its importance is such that Leuffer believes each community has created a determined social space somewhere in history to respond to all diverse needs in the space [34]. Therefore urban spaces via wide spectrum of addressees present with various motivations are the beds of social life happening... and have more impact than other spaces on social life and citizen's culture, urban spaces are the arena of social life and social interaction. In these spaces citizens gather to transform one to all, all who can exhibit collective abilities [35]. Richard Rogers also has acknowledged urban space a factor of society (presence) inducer and mobility in cities and 'Yan Gal has defined city attraction for people mass gathering in public spaces for spending their spare time' [35].

\subsubsection{Urban Spaces \& Ritual Ceremonies}

(Public space is as a joint bed where people perform their functional and ceremonial activities that connect community members whether by normal daily routine or periodical festivals [36]. That is why traditional ritual locations have significant symptoms rooted in culture and society. Ritual sites hold numerous events, ceremonies and incidents and create envisions and give significance to space. Traditional ritual sites are thumping heart of a city and spaces for establishing social interactions, sense of belonging increase, making sense of reminiscence and promotion of identity serve as lively and dynamic spaces that need more consideration for restructuring, reorganization and investment.

\section{Identification of Social Capital Booster Components in Ritual Spaces}

The most effective factor on urban public spaces can be studied in two groups of 'definition' and 'activity'. For the first group definition, 'identity' and 'beauty' and for the second group of activities, 'social interaction', 'sense of community' and 'satisfaction' can be considered. So, in general 'the physical characteristics of place is effective on activities and social interaction and enrichment of concepts and sense of place over the sense of location for users and this effect requires perception of cultural and social grounds' [36].Hummon has also discussed five types of sense of place from rooted belief, rooted subconscious, relative location and alienation of place and space' [37]. In addition, topics such as 'social belong to place effected by factors emanated from human and environment... and belong to place is to the sense of rooting in society' [31]. Belong to place occurs by establishing various connections formed by individuals and place' [38].

According to sense of place are somehow a combination of relation with place and a sense of presence in the community [38]. Shamai also specifies three main stages of 'belong to place', 'attachment to place' and 'commitment to place' in seven various levels [39]. Other experts further reckon tendency of 'community participation' an effective component of sense of place establishment and reinforcement [4]. 'Beliefs and creeds' are also other effective components on sense of place [4]. These components in addition to rooting in place and its sense of belonging, fortify connections and social communications more than previous, as shown in Table 2.

Table 2. Review of Effective Components on Urban Public Space and Citizens.

\begin{tabular}{|c|c|c|c|}
\hline Components & Definition & Effect(s) of Urban Spaces & Impact on Users \& Citizens \\
\hline $\begin{array}{l}\text { Attachment to } \\
\text { Place }\end{array}$ & $\begin{array}{l}\text { According to Mazzalo sense of attachment is } \\
\text { one of the main human needs. [4]. 'Attachment' } \\
\text { means that individual is sensitive in respect to } \\
\text { others, including sense of belonging, } \\
\text { satisfactory feeling and proud to be in society } \\
\text { and sense of security and comfort in society } \\
\text { [40]. }\end{array}$ & $\begin{array}{l}\text { Physical design of an effective } \\
\text { environment on sense of attachment to } \\
\text { place and user environment [41]. } \\
\text { Due to the possibility of occurrence a } \\
\text { social relation and mutual experience } \\
\text { among individual shapes sense of } \\
\text { belonging and attachment [42]. } \\
\text { Sense of belonging and attachment to } \\
\text { place, etc. (accompanies) continuation of } \\
\text { human presence in location [35]. }\end{array}$ & $\begin{array}{l}\text {-Mental visions; } \\
\text {-Beauty inspirations; } \\
\text {-identity; } \\
\text {-Satisfaction. }\end{array}$ \\
\hline $\begin{array}{l}\text { Belonging to } \\
\text { Place }\end{array}$ & $\begin{array}{l}\text { Sense of belonging is an important symptom } \\
\text { and factors in human evaluation; environment } \\
\text { and quality creation. At this level of } \\
\text { significance explains a type of individual } \\
\text { profound relation with environment and at this } \\
\text { stage a type of substantiation between self and } \\
\text { location is sensed. }\end{array}$ & $\begin{array}{l}\text { Sense of belonging has two physical and } \\
\text { social dimensions; the results indicate } \\
\text { the superiority of community belonging } \\
\text { to physical belonging in the } \\
\text { environment. [42]. }\end{array}$ & $\begin{array}{l}\text { Sense of belonging to place on one side } \\
\text { depends on individual characteristics and } \\
\text { features like: individual motivation, } \\
\text { competencies and recognition of place and } \\
\text { on the other roots in social interactions and } \\
\text { individual relations with others in the } \\
\text { environment }\end{array}$ \\
\hline $\begin{array}{l}\text { Commitment } \\
\text { to Place }\end{array}$ & $\begin{array}{l}\text { 'Commitment' is defined as investment on } \\
\text { customary practices and social conventions and } \\
\text { efforts to accomplish is favorable image. In } \\
\text { fact, commitment is a type of emotional and } \\
\text { psychological dependence to social }\end{array}$ & $\begin{array}{l}\text { Environment physical features are } \\
\text { effective on sense of place by creation of } \\
\text { significance and assurance of specific } \\
\text { activities. Assurance of activities is } \\
\text { created by satisfaction from environment }\end{array}$ & $\begin{array}{l}\text { Individual attraction for their presence in } \\
\text { the environment; } \\
\text { Anticipation of citizens needed activities } \\
\text { for their presence in the environment; } \\
\text { Intimacy in the environment; }\end{array}$ \\
\hline
\end{tabular}




\begin{tabular}{|c|c|c|c|}
\hline Components & Definition & Effect(s) of Urban Spaces & Impact on Users \& Citizens \\
\hline & $\begin{array}{l}\text { environment connecting individual to society } \\
\text { [4]. }\end{array}$ & $\begin{array}{l}\text { variable properties such as temperature, } \\
\text { noise and feasibility of individual } \\
\text { practices and social interaction }\end{array}$ & $\begin{array}{l}\text { Satisfaction; } \\
\text { Facilitation of establishing social } \\
\text { interaction created by static elements such } \\
\text { as dimensions, proportions and forms. } \\
\text { Space cognition and emotions is possible } \\
\text { by apprehension of significance, symbols } \\
\text { and beauty } \\
\text { Cognitive semantic space form and } \\
\text { identification [36]. }\end{array}$ \\
\hline $\begin{array}{l}\text { Social } \\
\text { Participation }\end{array}$ & $\begin{array}{l}\text { Participation in common activities boost } \\
\text { individual connection with social values and } \\
\text { regulations i.e. during activities, common } \\
\text { values and norms become psychological; } \\
\text { psychological compatible features are } \\
\text { reinforced and as a result assist in individual } \\
\text { socialization [4]. All in all for increased } \\
\text { participation and interaction in urban spaces } \\
\text { ritual of socialization is quite effective. }\end{array}$ & $\begin{array}{l}\text { Four main factors of convenience, } \\
\text { portrait, access and relation, application, } \\
\text { socialization in creation of favored } \\
\text { location is effective [44]. Therefore, } \\
\text { urban public spaces is prepared by these } \\
\text { four factors for citizens reception of } \\
\text { place and their tendency to participate }\end{array}$ & $\begin{array}{l}\text { Anticipation of appropriate grounds for } \\
\text { people's participation; } \\
\text { Public and social requirements } \\
\text { considerations and efforts to obviate by } \\
\text { using public capacities; } \\
\text { Consideration of collective values and } \\
\text { providing beds of public actions for their } \\
\text { observance. }\end{array}$ \\
\hline $\begin{array}{l}\text { Beliefs \& } \\
\text { Creeds }\end{array}$ & $\begin{array}{l}\text { Belief to the definition of admission of social } \\
\text { values and norms where components of belief } \\
\text { explains individual acceptance and creeds of } \\
\text { morale and social rules validity, his believe of } \\
\text { social values and morale norms and his } \\
\text { loyalty[4]. Beliefs and creeds are a part of } \\
\text { mental visions of human phenomena that on } \\
\text { these bases ceremonies and rituals which are } \\
\text { also a part of behavior form phenomena is } \\
\text { shaped [45]. }\end{array}$ & $\begin{array}{l}\text { Rites and ritual ceremonies cause } \\
\text { continuity of place } \\
\text { Survival. Therefore, 'places of rituals } \\
\text { sanctity of these ceremonies yield and } \\
\text { adds elegance and ceremony also } \\
\text { manifests in the ritual places physics and } \\
\text { this place is a separate factor that attracts } \\
\text { more people for participation in the } \\
\text { ceremony [45]. }\end{array}$ & $\begin{array}{l}\text { Market forecast is an appropriate physic for } \\
\text { celebration of creeds and rites } \\
\text { performance; } \\
\text { Consideration of establishing a space for } \\
\text { creeds exhibition. }\end{array}$ \\
\hline
\end{tabular}

\section{Identification of Effective Environmental Components on Public Ritual Spaces}

In view of the theory of place-behavior in environmental psychology for environmental classifications two important factors of 'activity' and 'physiques' have been discussed [43]. The ruling activities in environment are defined on the basis of social factors, human public deeds and interactions. Physique is also evaluated by organized form variables and components. 'Physical factors concerns environmental differentiation, space inner and outer relations to sense of belonging creation. Shape, size, color, texture and scale as form properties each have important effective role in shaping belonging to place and the type of organization and layout of the physical components is another effective factor. On the other hand, physical factor is solely effective by concords and capability to meet the man in space for sense of belonging creation' [43]. In designing each variables of color, shale, texture and scale and the type of organization based on human needs and providing the type of activity in concern for ritual spaces is also essential which explains the environmental features that flourish the form of performance[46]. On top, for furnishing the grounds of individual attraction of space like holding various traditional ritual ceremonies such as grieving (Taaziyeh), Moharram ceremonies, donations (Nazri), ceremonies, feasts and celebrations and other ancient and religious ceremonies must also be considered. On the other side to keep individuals in spaces with complete satisfaction, an appropriate physic such as beauty quality promotion, space identity including shape and view, construction of fountain, plants for air purification and softening, a place to rest and discussions, night illuminants and other symbolic elements are suggested[47].

\section{Summarize}

In general research findings clearly explain the fact that on top of ritual ceremonies, space physique is also effective in establishing social connections among people. Therefore, for designing spaces in addition to consideration of activity diversity of ritual ceremonies form and space physic must a dynamism and vitality ritual spaces also are regarded. Hence, surveys indicated that the most significant reason of dynamism and vitality ritual spaces at initiation for the cause of activity special features resulting from ritual beliefs and creeds that increment environmental attraction and vitality. Consequently, citizens by their voluntary presence in ritual ceremonies can attain a type of consubstantial with environment and this fact encourages sense of attachment and belonging to space. The appearance of sense of attachment and belonging to environment causes re attraction of citizens in practicing past experiences in space.

This matter increases the grounds for participation and collaboration outbreak in performance of activities that citizens upon their beliefs and creeds participate in holding ritual ceremonies. On the other side, appropriate apprehensible form, physically distinct and taking advantage of the elements and also ritual symbols assist in mental visualization and memorabilia that increase sense of attachment and commitment to place. All components for 
public space designing are effective actions for social capital growth and urban public spaces sustainability. Physical standards of urban public spaces in addition to ritual practices diversity in this space will also effect individual social connection, as presented in Table 3.

Table 3. Effective Components of Social Capital Creation \& Impacts in Urban Public Spaces.

\begin{tabular}{|c|c|c|c|}
\hline Related Implications to Social Capital & Environmental Quality & \multicolumn{2}{|c|}{ Effects on Urban Public Spaces } \\
\hline \multirow{2}{*}{$\begin{array}{l}\text { Attachment, Belonging and Commitment } \\
\text { to Place }\end{array}$} & Physical & \multicolumn{2}{|c|}{$\begin{array}{l}\text { Form, size, human scale, texture, color, light, relation, spatial sort and organization, } \\
\text { spatial hierarchy observance, visual appeals, inner and outer relations with } \\
\text { environment, centralism, ritual symbols, indicators, readability }\end{array}$} \\
\hline & Activity & \multicolumn{2}{|c|}{$\begin{array}{l}\text { To hold various traditional ritual ceremonies, activity and user diversity, social } \\
\text { events }\end{array}$} \\
\hline \multirow{4}{*}{ Social Participation \& Interaction } & & $\begin{array}{l}\text { Invitation } \\
\text { Effects }\end{array}$ & $\begin{array}{l}\text { Visual and physical access, replication to performance scale per } \\
\text { space, diversity and flexibility of spatial and activity in appealing } \\
\text { various groups, various social groups access. }\end{array}$ \\
\hline & Physical & Security & $\begin{array}{l}\text { Traffic control, night illuminants, protection of environmental and } \\
\text { climatic issues, establishing security and sense of safety, public } \\
\text { monitoring establishment }\end{array}$ \\
\hline & & Ideality & $\begin{array}{l}\text { Appropriate scale of effective behavior and senses in space, visual } \\
\text { appeals (appropriate design, views and perspectives, natural } \\
\text { factors, readability) }\end{array}$ \\
\hline & Activity & \multicolumn{2}{|c|}{$\begin{array}{l}\text { Activity replication: activity diversity and vitality, educational institutions, user } \\
\text { diversity, space active at various periods }\end{array}$} \\
\hline \multirow{2}{*}{ Beliefs \& Creeds } & Physical & \multicolumn{2}{|c|}{ Attraction and ideality, spatial hierarchy observance } \\
\hline & Activity & \multicolumn{2}{|c|}{ Holding various traditional ritual ceremonies, activity and user diversity } \\
\hline
\end{tabular}

\section{Discussion and Conclusion}

If rites are viewed as a resource and cultural capital, then urban public spaces based on cultural plan can have a decisive role in social capital production and sustainability establishment through consolidation and reinforcement of cultural identity and social solidarity. Religion, Islamic culture and its reflection in public spaces offers a special feature and that is city determinant. In this culture, ritual ceremonies epiphany of omniscient and sacred thinking enjoy exalted idealistic importance and ritual holding through special ceremonies and their performance during various periods and places and exclusive conditions, in its turn is effective in giving identity to the city and shaping of urban public spaces. Therefore, in view of each section of urban spaces have different functions and significance. The features of what citizens require increasing in conformity with spaces.

These spaces during specified times due to 'ritual spaces' is specifically important and by creation of sense of location established on the basis of attachment to place, sense of belonging to place and commitment to place is an appropriate bed for providing for the existence of social effective interaction and collective memories. This matter that itself has a direct relation with time and physique is effective on place identity that orients citizen's behaviors. Thereupon, one of the main issues that reinforces and fortifies place identity in cities is rites and ritual ceremonies heeds since in this way citizens can find opportunity to, on the basis of inner inclinations originating from religious beliefs and creeds, voluntarily and spontaneous participate effectively in social and cultural activities. For this reason, there is a direct relation between the role of rites and ritual ceremonies and its relations with citizen's attendance.

This issue is such important that rituals have serious impact on urban spatial structure. So, by better insight of rites, the features of ritual ceremonies (religious/cultural) and their application in programs and plans can greatly assist in establishing social sustainability and sense of place to urban public spaces which is adapted from components such as place attachment, sense of belonging, commitment, participation and reinforcement of creeds and religious beliefs. Performed surveys in this respect in view of studied summarized and also case sample studies were analyzed. As a whole, it seems not so essential for application in urban public spaces designing and to predict significant places for holding these rites and ritual religious ceremonies. Yet, it is necessary to consider feasible homogenous equal spaces to be able to perform various possible activities simultaneous. Furthermore, since the main ritual ceremonies are performed at specific time of year or week not as routine, citizen public spaces should not allocated for periodical or short term activities, instead space shall be designed such flexible and conversable that performance of any activity is quite feasible.

\section{References}

[1] Gehl, J. Public space, public life, Copenhangen: Danish architectural press. 2004. 
[2] Ghel,J, Life Between Building Using Public Space, Van Nostrand Reinhold, New York. 1987.

[3] Lennard \& Lennard. Public life in urban places, Godlier, Southampton. 1984.

[4] Rezaei Sharif, Ali, Connection with Schools: Theory and Research and , easurement procedures, Tehran, Diyar Publications, 2012.

[5] Benaim,A,AmberC.Collins,Luke,Raftis,.Exploring the social dimension of sustainable development, Sweden, School of Engineering Blekinge Institute of Technology Karlskrona, 2008.

[6] Estes,Richard,Social welfare and development, partners or competitors ,university of pennsylvania,2001.

[7] Johnston, Michael, social development as an anticorruption strategy, international anticorruption conference,cancun,guintana roo,mexico,1993.

[8] Ghaffari, Gholam Reza \& Omidi, Reza, Quality of Life Indicators of Social Development, Tehran, Shirazeh Publishers; 2009.

[9] Raeissi, Iman \& Habibi Abolfazl, Writing on Social Sustainability in Housing, Abadi Quarterly, 2009, No. 55;

[10] Habibi, Mohsen, Urban Spaces, True Life Events and Collective Memory, Safeh Journal, Ninth year, 2008, No. 28, spring and summer;

[11] Raco,M,"Building Sustainable Communities- Spatial Policy, Place Imagination and labour Mobility in post war in Britain”,Bristol,Policy Press,2007.

[12] UN-HABITAT, an asset-based approch to community development and capacity building. Nairobi: Earthscan publication. 2008.

[13] Eade, Deborah; Williams, Suzanne. The Oxfam Handbook of development and Relief. London: Oxfam Publication. 1995,

[14] De Vita, Carol J; Fleming, Cory; Twombly, Eric C. Building Noneprofit Capacity:A Framework for Addressing the Problem. In C. J. De Vita, \& C. Fleming, Building Capacity in Noneprofit Organizations ,2001, pp. 5-33, Washinton D.C : The Urban Institute.

[15] Grootaert, C , Social capital, the missing link, Social Bank, 1999. No. 14

[16] Shafeia, Saeed, The Study of the Relationship between Social Capital and Sustainable Development of Local Economy, 'Research on Informal Neighborhood New Shemiran Entrepreneurs, Proceedings of First Conference of Urban Economics, Mashhad, 2011, p. 1-16;

[17] Durkheim,E, Education and Sociology, Glencolll: Free Press, 1956.

[18] Bocock, R, Ritual in Industrial Society. London Allen \& Ynwin, 1974.

[19] Torabi, Ali Reza, City and Rituals, Municipalities Monthly, Fifth year, 2004, No. 59, p. 4;

[20] Ghorab, Nasser-Al-Din, Silent True Religion, Municipalities Quarterly, Fifth year, 2004, No. 59, p. 17;

[21] Hall,S, and Jefferson, T, Resistance through Rituals- Youth cultures in Post War Britian. London, Huchinson, 1976.

[22] Rouhl Amini, Mahmoud, Ancient Rituals and Celebrations in Iran Today, Tehran, Agah Publication, 1997.

[23] Carrier, Rob, Urban Spaces, Translated by Khosrow Hashemi, Khak Publications, Tehran, 2005.

[24] Bahreini, Hossein, Urban Design Process, Tehran University, Tehran, 2003.

[25] Habibi, Abolfazl, Housing Design Approach to Social Stability, Master thesis, Ghazvin Islamic Azad University, 2009, p. 17-18;

[26] Tanyks, Forn, Space, Urban and Social Theory (Social Ceremonies and Urban Forms), Translated by: Hamid Reza Parsi and others, Tehran University Publication, Tehran, 2009.

[27] Rapaport, A. The meaning of the Built Environment: A Nonverbal Communication, Arizona: University of Arizona press . 1990.

[28] Falahat, Mohammad Sadegh, The Sense of Place and its Constituent Elements, Tehran, Beauty Fine Arts, 2006, No. 26, p.57-66;

[29] Lynch, Quinn, The Theory of Urban Good Shape, Translated by Seyed Hossein Bahraini, Tehran, Tehran University Publications, 1997.

[30] Pir Babaei, Mohammad Taghi \& Sajadzadeh, Hassan, Collective attachment to place Realization of Social Housing in the Traditional Neighborhood, 2011, No. 16, Year 8, p. 17-28;

[31] Norberg- Shulz, Ch. The phenomenon of place, pricton Architecturak press, New York. 1997.

[32] Hayden,Dolores, What would a non- sexist city be like?, Speculations on housing, urban design and human work, in legates, Richard and Frederic stout, eds, the city reader, routledge, London,1996.

[33] Pakzad Jahanshah, Polls close on Public, Quarterly Journal of Architecture, 2007, eighth year, Nos. 29-30;

[34] Madanipour,A, Design of Urban Space: An inquiry into a socio-spatial process, Tehran, Press processing and urban planning, 2000.

[35] Falahat, Mohammad Sadegh, The Sense of Place and its Constituent Elements, Tehran, Beauty Fine Arts, 2006, No. 26, p.57-66;

[36] Hummon, D. Community Attachment: Local sentimant \& sense of place, plenum. New York. 1992.

[37] Cross, J.E. What is sense of place, Research on place \& space website, 20 feb. 2001.

[38] Shamai, Sh,Sense of place: An empirical measurement, Isreael, ceoforum . 1991. volume 22, pp. 347-358

[39] Maddox, S. J and Prinz, R. J. School bonding in children and adolescents: Conceptualization, assessment, and associated variables, Clinical Child and Family Psychology Review, . 2003, 6 (1), p: 31-49.

[40] Falahat, Mohammad Sadegh, 2005, The Physical Layout of a Sense of Place in the Mosque, Tehran, Beauty Fine Arts Journal, No. 22, p. 35-42; 
[41] Pakzad Jahanshah, Deep Thoughts on Urban, Tehran, Shahidi Publication, 2009.

[42] Javan Forouzandeh, Ali \& Motalebi, Ghassem, The Concept of Sense of Belonging to a Place and its Constituent Elements, Journal of Urban Identity, 2011, No. 8, p. 27-37;

[43] Modiri, Atoussa, Place, Urban Identity Publications, 2008, Second Year, No. 2, p. 69-79;
[44] Mir Shokraie, Mohammad, Market and Ritual Ceremonies, Arts Monthly, 2002, February\& March, p. 26-30;

[45] Motalebi, Ghassem, Recognition of Form and Function in Architecture, Beauty Fine Arts Journal, 2006, No. 25, p. 55-64;

[46] Khastov, Maryam \& Saeed Rezvani, Naveed, Factors Affecting the Vitality of Urban Spaces, Urban Identity Publishers, Fourth year, 2009, No. 6, p. 63-74; 